\title{
Analysis of the efficiency of insurance companies in Indonesia
}

\author{
Zaenal Abdin ${ }^{a^{*}}$, R. Mahelan Prabantarikso ${ }^{b}$, Edian Fahmy ${ }^{\mathrm{c}}$ and Ahmad Farhan ${ }^{\mathrm{d}}$
}

\author{
aPerbanas Institute, Jakarta, Indonesia \\ 'Perbanas Institute, Jakarta, Indonesia

\section{H R O N I C L E} \\ Article history: \\ Received August 10, 2021 \\ Received in revised format: \\ November 10, 2021 \\ Accepted January 102022 \\ Available online \\ January 10, 2022 \\ Keywords: \\ Data Envelopment Analysis \\ Insurance Companies \\ Tobit Model
}

${ }^{b}$ Sekolah Tinggi Ilmu Ekonomi Indonesia Banking School, Jakarta, Indonesia

${ }^{c}$ Universitas Pamulang, Tangerang Selaran, Banten, Indonesia

\begin{abstract}
A B S T R A C T
Financial system stability is not only supported by the banking sector, but also the role of insurance companies that operate efficiently. The study aims to analyze the efficiency performance of general insurance companies using two stages of data envelopment analysis during the $2017-2018$ period. The first stage of efficiency measurement using a non-parametric data envelopment analysis (DEA) approach shows the efficiency level of general insurance companies experiencing a positive trend. The performance of general insurance companies in 2018 was more efficient than in 2017 based on the value of technical efficiency (CRS) and the value of pure technical efficiency (VRS). This means that in general there has been an increase in the efficiency of general insurance companies in Indonesia from 2017 to 2018. Testing the efficiency determinants in the second stage using the Tobit regression model found that the cost ratio is the only factor that significantly influences the efficiency level of general insurance companies in Indonesia. Meanwhile, company ownership and investment adequacy ratio have no significant effect on the efficiency level of general insurance companies in Indonesia. The results of the study provide recommendations to the management of general insurance companies that efficiency performance has not reached the maximum, and to improve it, it is necessary to control costs without disturbing routine operations and development activities.
\end{abstract}

C) 2022 by the authors; licensee Growing Science, Canada.

\section{Introduction}

The stability of the financial system as a whole is not only supported by the banking sector, but also the role of insurance companies. The banking sector plays a special role in the financial system through the transmission of monetary policy, payment systems and reallocation of savings to investment. The role of insurance in economic development is as important as the role of banks, namely obtaining premiums from the public to carry out their operations as risk managers. The premiums obtained must be used by the company efficiently to be able to provide all the obligations of the insured and obtain optimal profits (Mohy ul din et al., 2017). In general, insurance company finances are a concern if the insurance company is declared bankrupt because policyholders and related parties will consider them to have serious problems (Marović et al., 2010). Therefore, it is very important for insurance companies to predict risk because it can affect the company's financial stability (Tsvetkova et al., 2019). Based on Insurance Statistics (OJK, 2018) the growth of general insurance gross premium income in 2018 was 9.79 percent, from 54.6 trillion rupiahs to 60 trillion rupiahs. Although there is growth, this figure is still far from the existing potential. In 2018, it was also recorded that the total equity of general

* Corresponding author.

E-mail address: zaenal@perbanas.id (Z.Abdin)

(C) 2022 by the authors; licensee Growing Science, Canada.

doi: $10.5267 / \mathrm{ds} 1.2022 .1 .002$ 
insurance was 55.2 trillion rupiahs, with total expenses of 32.3 trillion rupiahs. The total investment in 2018 was 71.92 trillion rupiahs. In today's era of globalization, insurance companies are required to operate in highly competitive conditions. In addition, insurance companies need to pay attention to efficiency in their operational activities. An insurance company can achieve maximum efficiency if the managed inputs can produce optimal output in various market conditions encountered. The achievement or failure of the company's performance efficiency is due to errors in managing its inputs and outputs (Otley, 1999). Through measuring the level of efficiency, policyholders and the public can find out the company's performance, so they can have more confidence in the company (Abidin et al., 2021), and are able to generate high profits for the benefit of the company owner (Endri et al., 2021)

The non-parametric method of data envelopment analysis (DEA) has been widely applied by previous researchers in measuring efficiency in insurance companies. The DEA method with a multi-input and output approach measures the relative efficiency of a series of Decision-Making Units (DMU). Early studies on the use of the DEA method for measuring efficiency in insurance companies were carried out by Cummins and Zi (1998), and Cummins et al. (1996), then continued in the 2000s, among others were carried out by Yao et al. (2007), Chen et al. (2011), Abidin and Cabanda (2011), AnsahAdu et al. (2012), Barros and Wanke (2016), and Nourani et al. (2018). The latest research on measuring the efficiency of insurance companies, among others, was carried out by Kaffash et al. (2020), Bansal and Singh (2021) and Pervan et al. (2021), however, the literature review shows that studies related to efficiency in insurance companies are still limited compared to other companies in financial institutions. Along with the times, the measurement of the level of efficiency using the DEA method has also developed, namely by providing additional analysis of the factors that are thought to influence the level of efficiency. The next analysis procedure can be referred to as Two-Stage Data Envelopment Analysis. According to Chen et al. (2010) in measuring efficiency using the Two-Stage DEA procedure, there are two stages in the analysis, in the first stage, measuring the level of efficiency using the traditional DEA approach, using data on input variables and output variables that desired. Next, in the second stage, perform a regression analysis by making the value of the efficiency level from the first stage as the dependent variable, while external factors as the independent variable. Furthermore, a different test analysis was conducted using the Mann-Whitney test to determine the difference in the efficiency level of national and foreign ownership insurance. The study of Kaffash et al. (2020) mentions that in the application of Two-Stage DEA to evaluate the relationship between factor and efficiency in insurance companies, various mathematical models including Tobit Regression and other models have been used.

Many previous studies have been carried out to measure the efficiency level of insurance companies, especially using the DEA method, but this study further measures what variables affect the level of insurance efficiency and finds out the difference in the efficiency level of insurance with national and foreign ownership. So, the purpose of this paper is to analyze the influence and efficiency level of general insurance companies in Indonesia for the period 2017 - 2018: A Two-Stage DEA.

\section{Literature Review}

In measuring the level of performance of an entity, efficiency is closely related to productivity, where efficiency and productivity describe the comparison between inputs and outputs (Abidin \& Endri, 2009). Efficiency is a measure of effectiveness without wasting time, effort and using minimum skills. Efficiency and effectiveness describe the performance of an entity. Efficiency is carried out to produce maximum output at the smallest cost (Jaouadi \& Zorgui, 2014), while effectiveness with a broader approach indicates the extent to which the actual results have been achieved to meet the desired results by doing things accurately (Endri, 2018; Kao \& Hwang, 2008).

In measuring the level of efficiency, it is influenced by: (a) Timeless, is a measurement of the extent to which an activity can be completed in the desired time, (b) Cost-effectiveness, measuring the extent to which the use of resources (financial, material, human, and technology) in optimizing outputs. According to Coelli (2005), efficiency can be measured by two approaches, namely the input-oriented approach, and the output-oriented approach. The input-oriented approach is used when an entity will reduce the level of the proportion of inputs to produce optimal output, while the output-oriented approach is where an entity will maximize its profits. Measuring the efficiency of a company, especially in the financial sector, can use several methods, namely parametric and non-parametric approaches (Dong et al., 2014). The method commonly used in efficiency research and used in this study is the non-parametric DEA method. The DEA method has been widely used by previous researchers to measure the level of efficiency in insurance companies (Eling \& Luhnen, 2010; Kaffash \& Marra, 2017; Akhtar, 2018; Anandarao et al., 2018; Almuhim, 2019; Ilyas \& Rajasekaran 2019; Fathi et al., 2020). As many as $42 \%$ of the 132 DEA studies on insurance companies occurred in 2010-2016 with the country that publishes the most research is the United States (Kaffash \& Marra, 2017). Abidin and Cabanda (2011) conducted a study of 23 general insurance companies in Indonesia using the input variables of administrative and business costs as well as marketing costs. For the output variable, premium income, net underwriting results, and investment returns are used. The results show that general insurance in Indonesia is not yet efficient, there are only 3 efficient general insurance companies. Gharahani et al. (2017) examined 30 non-life insurance companies in Iran during 2013-2015 using the Dynamic DEA approach with inputs of insurance costs, operational costs, and the number of workers, while for the output of stage 1 using direct premiums and reinsurance premiums and the output in stage 2 is underwriting profit, investment profit, and the amount of premium issued. This study shows that there is only 1 efficient DMU, all DMUs perform better in the first stage but the trend over the study 
period is not clear. 1 Efficient DMUs that use fewer inputs technically operate better than other DMUs that use more inputs to produce larger outputs. Research conducted by Almuhim (2019) on 26 conventional insurance companies and 7 takaful insurance companies in 2014-2017 with Two-Stage DEA shows that the DEA scores of the two types of insurance companies on average decreased, but takaful insurance companies performed better than other insurance companies conventional insurance because as a financial intermediary able to combine various optimal outputs through several lines of business.

The research that carried out the second stage was to identify the factors that affect the efficiency of insurance companies because the censored DEA data used a lot of Tobit regression models. The research of Grmanová and Strunz (2017) with a sample of 15 insurance companies in Slovakia during 2013 - 2015, using DEA, Tobit regression models, and Mann-Whitney concluded that technical efficiency is not affected by Return on Assets and Return on Equity. Suárez-Álvarez et al. (2016) conducted a study of 424 life and non-life insurance companies in Europe. The study was conducted to find the effect between the efficiency of the company and the financial health of the company which was measured using financial ratios. By using DEA and the Tobit regression model, the results show that companies that have good financial health also get good efficiency scores. Other efficiency studies also use Two-Stage efficiency, namely DEA and Tobit in the financial services sector such as banks (Singh \& Fida 2015; Batir et al., 2017; Almanza \& Rodriguez 2018). Research conducted by $\mathrm{Hu}$ et al. (2009) in China showed that the efficiency level of insurance companies fluctuated where the highest point was reached in 1999 and 2000. This study also shows that market power, distribution channels, and ownership affect the level of efficiency. Ownership has an influence on efficiency in insurance companies is also found in research by Viverita et al. (2016) and Wicaksono and Mulyaningsih (2019), however, Cummins and Xie (2016) who researched the determinants of the efficiency of insurance companies in America for the period 1993-2011, by looking at their relationship with ownership structure, distribution, and product strategy, which proved that ownership structure did not affect efficiency in insurance companies. The Mann-Whitney test complements the measurement of the level of efficiency using DEA and Tobit regression, such as the research conducted by Owusu-Ansah et al. (2010), where DEA is used to measure the efficiency level of general insurance companies in Ghana from 2002-2007 and conducted a different test with the Mann Whitney Test between insurance company sizes and market share which gave the result that large company sizes have high-efficiency differences compared to the size of the company is small, the next result is that insurance companies with a market share also have a high level of efficiency difference compared to insurance companies with low market share. These two results mean that insurance companies need to increase the size of their market share companies to achieve maximum efficiency. Nourani et al. (2017) evaluated efficiency performance with the Dynamic DEA approach on 3 types of insurance companies, namely life insurance, general insurance, and composite insurance as well as the difference between national and foreign ownership using the Kruskal-Wallis test in Malaysia for the 2007-2014 period. This study shows that composite insurance performs better on investment adequacy, whereas general insurance performs better on the premium accumulation function. Foreign ownership is more efficient than national ownership, this is due to poor performance on investment. Lee et al. (2018) used the DEA method to measure the level of Technical, Pure Technical, and Scale Efficiency in takaful insurance companies in Malaysia, Panzar-Roze (PR) H-statistics to measure competition between Takaful Insurance and the Mann Whitney test difference test which measures differences in efficiency levels between General and Family Takaful Insurance from 2012-2015 which gives the result that in general, of the three efficiency levels during the study period there is a significant difference between Family and General Takaful Insurance, Family Takaful Insurance has a higher efficiency level than General Takaful Insurance. Bansal and Singh (2021) with a sample of 60 insurance companies listed on the stock exchanges of six GCC countries during 2016-2019, comprehensively measure technical efficiency with a two-stage analysis. The measurement of the technical efficiency of the GCC insurance company in the first stage shows a CAGR value of $2.13 \%$ and a CAGR scale efficiency of $2.96 \%$. For the second stage using the Tobit regression model, it is proven that competition and financial freedom can improve the technical efficiency of insurance companies. The research of Wasseja and Mwenda (2015) with a sample of life insurance companies in Kenya, measuring the level of efficiency using DEA and Mann Whitney Test to see differences in efficiency levels from year to year during the research period, namely 2004-2009 which then obtained the results that there was a significant difference in the form of a decrease in efficiency levels every year.

\section{Research Method}

\subsection{Research Sample}

This study uses quantitative data with the DEA stage method to explain the efficiency performance and its determinants. The data is sourced from the annual financial reports of general insurance companies during the 2017-2018 period. The population is all public companies registered with the Financial Services Authority (OJK) and the sample selection is based on the following criteria:

1. General Insurance Company in Indonesia that is actively operating research.

2. Companies that publish annual financial reports during the research period and are attached to the Infobank magazine.

3. Insurance companies have a capital of 100 billion rupiah - 1 trillion rupiahs.

So that in this study there was a sample of 18 general insurance companies that match the criteria above. Of the 18 insurance companies, there are 8 foreign-owned insurance companies and 10 national-owned insurance companies. 
Table 1

List of Sample Names of General Insurance Companies

\begin{tabular}{llll}
\hline No & Company & No & Company \\
\hline 1 & Sinar Mas Insurance & 10 & Reliance Indonesia Insurance \\
2 & Indonesian Service Insurance & 11 & Tokio Marine Indonesia Insurance*) \\
3 & Brins General Insurance & 12 & MSIG Indonesia Insurance*) \\
4 & Indonesian Credit Insurance & 13 & Indonesian FPG Insurance*) \\
5 & BCA General Insurance & 14 & Dayin Mitra Insurance*) \\
6 & Jasaraharja Son & 15 & AIG Insurance Indonesia*) \\
7 & Ramayana Insurance & 16 & China Taiping Insurance Indonesia*) \\
8 & Mustika Protector Partner Insurance & 17 & OTO Sumit Insurance*) \\
9 & Mitra Kresna Insurance & 18 & Samsung Tugu Insurance*) \\
\hline Source: Research Bureau of Bank Info Magazine, March 2019 & $*$ ) Foreign-owned insurance
\end{tabular}

\subsection{Analysis Tool}

To calculate the level of efficiency using the Max DEA software and the Tobit regression model to estimate the factors that affect the level of efficiency with the statistical program Eviews. The measurement of DEA efficiency in the first stage uses input data (capital and expenses) and output data (primary gross and investment). The MaxDEA software will calculate the efficiency value of general insurance companies based on output orientation and then compare the efficiency values between companies so that there are general insurance companies that become benchmarks for other insurance companies. The second stage identifies the factors that determine the efficiency of DEA. The second stage identifies the factors that determine the DEA efficiency of general insurance companies, in this study the factors used are company ownership, expense ratios, and investment adequacy ratios. The regression equation will produce an estimate of the relationship that can be used to predict the output outcome at a certain input level (Benarda et al., 2016). The Tobit Regression Model is as follows:

Information:

$$
E F T i=\beta_{1}+\beta_{2} K P M i+\beta_{3} R B N i+\beta_{4} R K I i+\varepsilon_{i}
$$

$$
\begin{array}{ll}
\mathrm{EFT}=\text { Data Envelopment Analysis }(\mathrm{DEA}) \text { Score } & \mathrm{RBN}=\text { Expense Ratio } \\
\mathrm{KPM}=\text { Company Ownership } & \mathrm{RKI}=\text { Investment Adequacy Ratio }
\end{array}
$$

The Mann-Whitney test was applied to see the difference in efficiency levels between national insurance and foreign insurance in Indonesia. The test criteria are if the significance value is less than $\alpha=0.05$ then Ho is rejected with a decision that there is a difference in efficiency level, otherwise if the significance value is greater than $\alpha=0.05$ then Ho is accepted with the conclusion that there is no difference in efficiency level.

\section{Results and Discussion}

\subsection{DEA Efficiency Measurement}

In this study, the Decision-Making Unit (DMU) consists of 18 (eighteen) General Insurance so that there are 36 DMU. A DMU is considered efficient if it has a value of 1 . Inefficiency can be seen from the value which is less than 1 . In this study, the efficiency calculation was processed using MaxDEA 7.0 software. The following describes the efficiency value of General Insurance each year based on the results of processing DEA. During 2017, there were 3 (three) insurance companies that were both technically efficient (CRS) and purely technically (VRS) all three insurance companies belonging to foreign companies. In addition, there are 6 (six) insurance companies that are purely technically efficient (VRS), but technically inefficient (CRS). Meanwhile, there were 12 (twelve) general insurance companies that were inefficient in 2017 both technically (CRS) and purely technical (VRS). Judging from the return to scale condition, there were 3 (three) insurance companies that were in constant condition, 13 (thirteen) insurance companies are in decreasing condition and 2 (two) insurance companies are in increasing condition. During 2018, 4 insurance companies were both technically efficient (CRS) and purely technical (VRS) and the 4 companies were owned. In addition, there are 7 purely technically efficient insurance companies (VRS), but technically inefficient (CRS). Meanwhile, 11 general insurance companies were inefficient in 2017 both technically and purely technically. Judging from the conditions of return to scale, 4 insurance companies are in a constant condition and 14 insurance companies are in a decreasing condition. Based on the calculation of DEA in 2017 and 2018, there are only 7 DMUs out of 36 Technically efficient DMUs. As for purely technically (VRS), there are 13 DMUs out of 36 efficient DMUs. The percentage efficiency level of DMU of general insurance companies is 19.4 percent for technical efficiency and 36.1 percent for pure technical efficiency. It can also be seen that China Taiping Insurance Indonesia and Sumit OTO Insurance are the most efficient General Insurance Company's DMU, while Samsung Tugu Insurance is the most inefficient General Insurance Company's DMU. Based on DEA calculations in 2017 and 2018, it can be seen that only 7 DMUs out of 36 technically efficient DMUs (CRS). As for purely technical terms (VRS), there are 13 DMUs out of 36 efficient DMUs. DMUs of general insurance companies that are efficient in percentage are 19.4 percent for CRS and 36.1 percent for VRS of the total number of DMU. This shows the similarity in the research of Grmanová and Strunz (2017) where general insurance companies in Indonesia are more efficient in purely technical terms (VRS) than technically (CRS). It can also be seen that the average efficiency level of general insurance companies in Indonesia is above 50 percent both technically (CRS) and purely technical (VRS) this is by the research of Abidin and Cabanda (2011). Sumit OTO Insurance 
Company and China Taiping Insurance Indonesia became efficient companies for 2 (two) consecutive years based on the value of CRS and VRS. The small number of efficient general insurance companies is by research conducted by Abidin and Cabanda (2011).

Table 2

General Insurance Efficiency Level in 2017

\begin{tabular}{|c|c|c|c|c|}
\hline No & Company & CRS & VRS & RTS \\
\hline 1 & Sinar Mas Insurance & 0.744201 & 1 & Decreasing \\
\hline 2 & Indonesian Service Insurance & 0.480805 & 0.981443 & Decreasing \\
\hline 3 & Brins General Insurance & 0.699836 & 0.859642 & Decreasing \\
\hline 4 & Indonesian Credit Insurance & 0.66294 & 1 & Decreasing \\
\hline 5 & BCA General Insurance & 0.678677 & 0.98044 & Decreasing \\
\hline 6 & Jasaraharja Son & 0.536786 & 0.670837 & Decreasing \\
\hline 7 & Ramayana Insurance & 0.718116 & 0.875343 & Decreasing \\
\hline 8 & Mustika Protector Partner Insurance & 0.580866 & 0.63335 & Decreasing \\
\hline 9 & Mitra Kresna Insurance & 0.730342 & 0.806195 & Decreasing \\
\hline 10 & Reliance Indonesia Insurance & 0.481334 & 0.502153 & Decreasing \\
\hline 11 & Tokio Marine Indonesia Insurance*) & 0.647878 & 0.816809 & Decreasing \\
\hline 12 & MSIG Indonesia Insurance*) & 0.865253 & 1 & Decreasing \\
\hline 13 & Indonesian FPG Insurance*) & 0.966371 & 0.98616 & Increasing \\
\hline 14 & Dayin Mitra Insurance*) & 1 & 1 & Constant \\
\hline 15 & AIG Insurance Indonesia*) & 0.88608 & 0.933319 & Decreasing \\
\hline 16 & China Taiping Insurance Indonesia*) & 1 & 1 & Constant \\
\hline 17 & OTO Sumit Insurance*) & 1 & 1 & Constant \\
\hline 18 & Samsung Tugu Insurance*) & 0.431002 & 0.431027 & Increasing \\
\hline
\end{tabular}

Source: Data processed using MaxDEA 7.0, 2019

Table 3

General Insurance Efficiency Level in 2018

\begin{tabular}{|c|c|c|c|c|}
\hline No & Company & CRS & VRS & RTS \\
\hline 1 & Sinar Mas Insurance & 0.666273 & 1 & Decreasing \\
\hline 2 & Indonesian Service Insurance & 0.480059 & 0.963193 & Decreasing \\
\hline 3 & Brins General Insurance & 0.760152 & 0.94017 & Decreasing \\
\hline 4 & Indonesian Credit Insurance & 0.673319 & 1 & Decreasing \\
\hline 5 & BCA General Insurance & 0.681816 & 1 & Decreasing \\
\hline 6 & Jasaraharja Son & 0.569059 & 0.70549 & Decreasing \\
\hline 7 & Ramayana Insurance & 0.710634 & 0.880261 & Decreasing \\
\hline 8 & Mustika Protector Partner Insurance & 0.581794 & 0.676241 & Decreasing \\
\hline 9 & Mitra Kresna Insurance & 0.777007 & 0.869379 & Decreasing \\
\hline 10 & Reliance Indonesia Insurance & 0.532964 & 0.589671 & Decreasing \\
\hline 11 & Tokio Marine Indonesia Insurance*) & 0.70281 & 0.91154 & Decreasing \\
\hline 12 & MSIG Indonesia Insurance*) & 0.81569 & 0.981081 & Decreasing \\
\hline 13 & Indonesian FPG Insurance*) & 1 & 1 & Constant \\
\hline 14 & Dayin Mitra Insurance*) & 0.946318 & 0.97034 & Decreasing \\
\hline 15 & AIG Insurance Indonesia*) & 1 & 1 & Constant \\
\hline 16 & China Taiping Insurance Indonesia*) & 1 & 1 & Constant \\
\hline 17 & OTO Sumit Insurance*) & 1 & 1 & Constant \\
\hline 18 & Samsung Tugu Insurance*) & 0.408356 & 0.411504 & Decreasing \\
\hline
\end{tabular}

Source: Data processed using MaxDEA 7.0, 2019

\subsection{DEA Determinants: Tobit Regression}

Table 4

Results of the Tobit Model Analysis

\begin{tabular}{llll}
\hline & Variable & Coefficient & p-Value \\
\hline Company Ownership & -0.046942 & 0.4121 \\
Load Ratio & -0.409174 & 0.0011 & 0.6629 \\
Investment Adequacy Ratio & 0.015199 & \\
\hline
\end{tabular}

Source: Data processed using Eviews 9.0, 2019

Based on the results of the analysis in Table 4, the results of Tobit model processing indicate that there are variables that have an influence or variables that do not. Firm ownership has no effect on DEA efficiency, and this finding supports the study of Cummins and Xie (2013), however, this result is not by research which states that company ownership affects the level of efficiency (Hu et al., 2009; Viverita et al., 2016; Nourani, 2017; Wicaksono \& Mulyaningsih, 2019). The cost ratio has a negative effect on the level of efficiency, meaning that an increasing cost ratio causes the efficiency level of general insurance companies to decrease. This finding is in line with Gharakhani et al. (2017) who in their research found that DMU uses a large amount of load on inputs but the output produced is quite low, especially on the number of premiums and investment returns. The Investment Adequacy Ratio does not affect the DEA efficiency of general insurance companies. These results do not support the study of Nourani et al. (2017) which concludes that the low level of efficiency in national 
insurance companies is caused by the low performance of investment ability of investment and Anandaro et al. (2018) which states that insurance companies with leading investment stages have better efficiency performance.

\subsection{Mann Whitney Different Test}

The different test is used to see the difference in DEA efficiency between National and Foreign Insurance using SPSS software. The results of the different tests are as follows:

Table 5

Results of the Mann Whitney Different Test

\begin{tabular}{llcc}
\hline Insurance company & Mean Rank & Value of Mann Whitney & Sig. Value \\
\hline National & 13.40 & 58.000 & 0.001 \\
Foreign & 24.88 & & \\
\hline Source: Data processed using SPSS, 2019 &
\end{tabular}

The Mann-Whitney difference test shown in Table 5 obtained a value of 0.001 which has a value smaller than $=0.05$ which means that the level of efficiency between National and Foreign General Insurance is different using the Technical Efficiency Score (CRS) method. From the results of the different tests above, which have differences in the two objects of the insurance group, the findings support the study of Owusu-Ansah et al. (2010), Lee et al. (2018), and Wasseja and Mwenda (2015) who get significant differences from insurance companies. Yao et al. (2017) have also tested the difference in efficiency levels between National and Foreign Ownership Insurance, where the findings reveal that state-owned insurance has a lower efficiency level than non-state insurance. Furthermore, in the research of Nourani et al. (2017) there is a significant difference between National and Foreign Ownership Insurance because foreign ownership can better utilize resources from technological advances and service quality.

\subsection{Discussion}

Empirical evidence finds that the variable of firm ownership is considered to not affect DEA efficiency which supports the findings of Cummins and Xie (2016). The managerial ownership of a large company has an effective impact in supervising the company's activities (Nguyen et al., 2020; Sugianto et al., 2020). Ali et al. (2008) state that if managerial ownership is low, the incentives issued to monitor the possibility of a manager's opportunistic behavior will increase. Empirical evidence also supports research by Eling and Luhnen (2010) which states that full company ownership will further improve company performance. Several studies were conducted, among others by; Hu et al., (2009), Viverita et al., (2016), and Wicaksono and Mulyaningsih, 2019 revealed the results that company ownership affects different levels of efficiency with the findings of this study. Karbhari et al. (2018) also prove that institutional ownership increases the efficiency of the Takaful industry. The company's operational activities are strongly supported by the adequacy of investment in the company (Endri et al., 2020). This is in line with the study of Sunaryo et al. (2020), and Nourani (2017) found that the investment adequacy ratio influences the efficiency of company performance. However, this is inversely proportional to the results in this study which shows that the investment adequacy ratio does not have an effect on the efficiency level of general insurance companies in Indonesia. The findings of Nourani et al. (2018) revealed that the total lack of investment is the key to the inefficiency of insurance companies in Malaysia.

\section{Conclusion}

The empirical findings of the research during the 2017 - 2018 period, the efficiency level of general insurance companies experienced a positive trend. The performance of general insurance companies in 2018 was more efficient than in 2017 based on the value of technical efficiency (CRS) and the value of pure technical efficiency (VRS). This means that in general there has been an increase in the efficiency of general insurance companies in Indonesia from 2017 to 2018 . In this study, Sumit OTO Insurance became the most efficient general insurance company and Samsung Tugu Insurance became the general insurance company that experienced the greatest inefficiency. The expense ratio is the only factor that influences the efficiency level of general insurance companies in Indonesia. Meanwhile, company ownership and investment adequacy ratio do not affect the efficiency level of general insurance companies in Indonesia. Insurance with national and foreign ownership has different efficiency levels where foreign-owned companies are better.

\section{References}

Abidin, Z., \& Cabanda, E. (2011). Efficiency Of Non-Life Insurance In Indonesia. Journal of Economics, Business, \& Accountancy Ventura, 14(3), 197-202. https://doi.org/10.14414/jebav.v14i3.46

Abidin, Z., Prabantarikso, R.M., Waedhani, R.A., \& Endri, E. (2021). Analysis of Bank Efficiency Between Conventional Banks and Regional Development Banks in Indonesia. Journal of Asian Finance, Economics, and Business, 8(1),741750. https://doi.org/10.13106/jafeb.2021.vol8.no1.741

Abidin, Z., \& Endri, E. (2009). Kinerja Efisiensi Teknis Bank Pembangunan Daerah: Pendekatan Data Envelopment Analysis (DEA), Jurnal Akuntansi dan Keuangan, 11(1), 21-29. https://doi.org/10.9744/jak.11.1.pp.\%2021-29 
Ali, S. M., Salleh, N. M., \& Hassan, M. S. (2008). Ownership structure and earnings management in Malaysian listed companies: The size effect. Asian Journal of Business and Accounting, 1(2), 89-116

Ansah-Adu, K., Andoh, C., \& Abor, J. (2012). Evaluating the cost efficiency of insurance companies in Ghana. Journal of Risk Finance, 13(1), 61-76. https://doi.org/10.1108/15265941211191949

Akhtar, M. H. (2018). Performance analysis of Takaful and conventional insurance companies in Saudi Arabia. Benchmarking: An International Journal, 25(2), 677-18. doi:10.1108/BIJ-01-2017-0018

Almanza, C., \& Rodríguez, J.J.M. (2018). Profit efficiency of banks in Colombia with undesirable output: a directional distance function approach. Economics, 12, 1-18. https://doi.org/10.5018/economics-ejournal.ja.2018-30

Almulhim, T. (2019). Analysis of Takaful vs. Conventional insurance firms' efficiency: Two-stage DEA of Saudi Arabia's insurance market. Cogent Business \&Management, 6(1), 1633807. https://doi.org/10.1080/23311975.2019.1633807

Anandarao, S., Durai, S.R.S., \& Goyari, P. (2018). Efficiency decomposition in two-stage Data Envelopment Analysis: An application to Life Insurance companies in India. Journal of Quantitative Economics, 17(2), 271-285. DOI: https://doi.org/10.1007/s40953-018-0148-1

Bansal, R., \& Singh, D. (2021). Efficiency drivers of insurers in GCC: an analysis incorporating company-specific and external environmental variables. Cogent Economics \& Finance, 9(1), 1922179. DOI: 10.1080/23322039.2021.1922179

Barros, C., \& Wanke, P. (2016). Cost efficiency of African insurance companies using a finite mixture model. South African Journal of Economic and Management Sciences 19(1), 64-81. https://doi.org/10.4102/sajems.v19i1.1238

Batir, T. E., Volkman, D. A., \& Gungor, B. (2017). Determinants of bank efficiency in Turkey: Participation banks versus conventional banks. Borsa Istanbul Review, 17(2), 86-96. https://doi.org/10.1016/j.bir.2017.02.003

Benarda, B., Sumarwan, U., \& Hosen, M.N. (2016). Tingkat Efisiensi Industri Asuransi Jiwa Syariah Menggunakan Pendekatan Two Stages Data Envelopment Analysis. Jurnal Aplikasi Bisnis dan Manajemen, 2(1), 64. doi: 10.17358/JABM.2.1.64

Chen, Y., Cook, W. D., \& Zhu, J. (2010). Deriving the DEA frontier for two-stage processes. European Journal of Operational Research, 202(1), 138-142. https://doi. org/10.1016/j.ejor.2009.05.012

Chen, L.-R., Lai, G. C., \& Wang, J. L. (2011). Conversion and efficiency performance changes evidence from the U.S. property-liability insurance industry. The Geneva Risk and Insurance Review 36(1), 1-35. https://doi.org/10.1057/grir.2010.3

Coelli, T. J., Rao, D. S. P., O’Donnell, C. J., \& Battese, G. E. (2005), An introduction to efficiency and productivity analysis, Springer Science \& Business Media.

Cummins, J.D., \& Xie, X. (2013). Efficiency, productivity, and scale economies in the US property-liability insurance industry. Journal of Productivity Analysis, 39(2), 141-164.

Cummins, J. D., \& Zi, H. (1998). Measuring economic efficiency of the US life insurance industry: econometric and mathematical programming techniques. Journal of Productivity Analysis, 10, $131-145$. https://doi.org/10.1023/A:1026402922367

Cummins, J. D., Turchetti, G., \& Weiss, M. A. (1996). Productivity and technical efficiency in the Italian insurance industry. Wharton School Center for Financial Institutions, University of Pennsylvania, Working Paper.

Dong, Y.Z., Hamilton. R., \& Tippett, M. (2014) Cost efficiency of the Chinese banking sector: a comparison of stochastic frontier analysis and data envelopment analysis. Economic Modelling, 36, 298-308. HTTPS:// doi.org/10.1016/j.econmod.2013.09.042

Endri, E., Ridho, A.M., Marlapa, E., \& Susanto, H. (2021). Capital Structure and Profitability: Evidence from Mining Companies in Indonesia. Montenegrin Journal of Economics, 17(4), 135-146. DOI: 10.14254/1800-5845/2021.17-4.12

Endri, E., Marlina, A., \& Hurriyaturrohman (2020). Impact of internal and external factors on the net interest margin of banks in Indonesia. Banks and Bank Systems, 15(4), 99-107. doi:10.21511/bbs.15(4).2020.09

Endri, E. (2018). Impact of Intellectual Capital and Efficiency on the Profitability of Islamic Banking. International Journal of Science and Research (IJSR), 7(7), 230-237.

Eling, M., \& Luhnen, M. (2010). Efficiency in the international insurance industry: A cross-country comparison. Journal of Banking \& Finance, 34(7), 1497-1509. doi:10.1016/j.jbankfin.2009.08.026

Fathi, M.R., Safari, H., \& Jafarzadeh, A.H. (2020). Evaluation of the branches of Iran Insurance Corporation based on data envelopment analysis-free disposal hull in the presence of weight restrictions. International Journal of Mathematics in Operational Research, 16(2), 202-201. DOI:10.1504/IJMOR.2019.10021405

Gharakhani, D., Eshlagy, A. T., Hafshhejani, K.F., Mavi, R.K., \& Lotfi, F.H. (2017). Common weights in dynamic network DEA with goal programming approach for performance assessment of insurance companies in Iran. Management Research Review, 41(8), 920-938. DOI: 10.1108/MRR-03-2017-0067

Grmanová, E., \& Strunz, H. (2017). The efficiency of insurance companies: Application of DEA and Tobit analyses. Journal of International Studies, 10(3), 250-263. https://doi.org/10.14254/2071- 8330.2017/10-3/18

$\mathrm{Hu}$, X., Zhang, C., Hu, J.L., \& Zhu, N. (2009). Analyzing efficiency in the Chinese life insurance industry. Management Research News, 32, 905-920. https://doi.org/10.1108/01409170910994123

Ilyas, A.M., \& Rajasekaran, S. (2019). An empirical investigation of efficiency and productivity in the Indian non-life insurance market. Benchmarking: An International Journal, 26(7), 2343-2371. https://doi.org/10.1108/BIJ-01-20190039

Jaouadi, S., \& Zorgui, I. (2014). Exploring Effectiveness and Efficiency of Banks in Switzerland. International Journal of Academic Research in Business and Social Sciences, 4(4), 313-325. https://doi.org/10.6007/IJARBSS/v4-i4/787 
Kaffash, S., Azizi, R., Huang, Y., \& Zhu, J. (2020). A survey of data envelopment analysis applications in the insurance industry 1993-2018. European Journal Operational Research, 284, 801-813. https://doi.org/10.1016/j.ejor.2019.07.034

Kaffash, S., \& Marra, M. (2017). Data envelopment analysis in financial services: A citations network analysis of banks, insurance companies, and money market funds. Annals of Operations Research, 253(1), 307-344. doi:10.1007/s10479016-2294-1

Kao, C., \& Hwang, S.N. (2008). Efficiency decomposition in two-stage data envelopment analysis: An application to nonlife insurance companies in Taiwan. European Journal of Operational Research, 185(1), $418-429$. https://doi.org/10.1016/J. EJOR.2006.11.041.

Karbhari, Y., Muye, I., Hassan, A. F. S., \& Elnahass, M. (2018). Governance mechanisms and efficiency: Evidence from an alternative insurance (Takaful) market. Journal of International Financial Markets, Institutions, and Money, 56, 7192. https://doi.org/10. 1016/j.intfin.2018.02.017

Lee, H.S., Chieng, F.F., \& Nassir, A. Md. (2018). Does Efficiency Promote Competitiveness of The Insurance Industry?. Journal of Business Economics and Management, 19(4), 566-591.https://doi.org/10.3846/jbem.2018.5547

Marović, B., Njegomir, V., \& Maksimović R. (2010). The Implications of the Financial Crisis to the Insurance Industry Global and Regional Perspective. Economic Research-Ekonomska Istraživanja, 23(2), 127-141, DOI: 10.1080/1331677X.2010.11517417

Mohy ul din, S., Regupathi, A., \& Abu-Bakar, A. (2017). Insurance effect on economic growth - among economies in various phases of development. Review of International Business and Strategy, 27(4), 501519. https://doi.org/10.1108/RIBS-02-2017-0010

Nguyen, A. H., Doan, D. T., \& Nguyen, L. H. (2020). Corporate governance and agency cost: Empirical evidence from Vietnam. Journal of Risk and Financial Management, 13, 103. DOI/10.3390/ jrfm13050103

Nourani, M., Devadason, E. S., \& Chandran, V. (2018). 'Measuring technical efficiency of insurance companies using dynamic network DEA: An intermediation approach'. Technological and Economic Development of Economy, 24(5), 1909-1940. https://doi.org/10. 3846/20294913.2017.1303649

Owusu-Ansah, E., Dontwi, I.K., Seidu B., Abudulai, G., \& Sebil, C. (2010). Technical efficiencies of Ghanaian general insurers. American Journal of Social and Management Sciences, 1(1), 75-87.doi:10.5251/ajsms.2010.1.1.75.87

Otley, D. (1999). Performance management: A framework for management control systems research. Management Accounting Research, 10(4), 363-382. https://doi.org/10.1006/mare.1999.0115

Pervan, M., Curak, M., \& Kramarić, T. P. (2021). Has Accession to the European Union Affected the Efficiency of Croatian Insurance Companies?. Zagreb International Review of Economics and Business, 24 (1), 67-98. https://doi.org/10.2478/zireb-2021-0004

Singh, D., \& Fida, B.S. (2015). Technical efficiency and its determinants: an empirical study on banking sector of Oman. Problems and Perspectives in Management, 13(1), 168-175.

Suárez-Álvarez, E., Quiroga-Garcia, R., Manzano-Perez, I., Lopez-Mielgo, N. (2016). Efficiency and Financial Health in the European Insurance Market. Journalof International Business andEconomics, 4(2), $29-40$. DOI:10.15640/jibe.v4n2a4

Sugianto, S., Oemar, F., Hakim, L., \& Endri, E (2020). Determinants of Firm Value in the Banking Sector: Random Effects Model. International Journal of Innovation, Creativity, and Change, 12(8), 208-218.

Sunaryo S., Santoni, A., Endri, E., \& Harahap, M.N. (2020). Determinants of Capital Adequacy Ratio for Pension Funds: A Case Study in Indonesia. International Journal of Financial Research, 11(4): $203-213$. https://doi.org/10.5430/ijfr.v11n4p203.

Tsvetkova, L., Yurieva, T., Orlaniuk-Malitskaia., \& Plakhova, T. (2019). Financial Intermediary and Insurance Companies: Assessing Financial Stability. Montenegrin Journal of Economics, 15(3), 135-146. DOI: 10.14254/1800-5845/2019.153.14

Viverita, V., Wulandari, S., \& Cabanda, E. (2016). Determinants of Cost Efficiency and Productivity Growth of the Indonesian Insurance Industry. International Journal of Knowledge-Based Organizations, 6(2), 70-82. doi:10.4018/IJKBO.2016040105

Wasseja, M.M., Mwenda, S.N. (2015). Analysis of the Efficiency of Life Assurance Companies in Kenya Using the DEAModel. American Journal of Mathematics and Statistics, 5(2), 60-71. doi:10.5923/j.ajms.20150502.03

Wicaksono, R., \& Mulyaningsih, T. (2019). Does ownership structure matter? A cost-efficiency study of life insurance firms in Indonesia. Buletin Ekonomi Moneter Dan Perbankan,22(3), $367 \quad-\quad 382$. doi:https://doi.org/10.21098/bemp.v22i3.957

Yao, S., Han, Z., \& Feng, G. (2007). On Technical Efficiency of China's Insurance Industry After WTO Accession, China Economic Review, 18(1), 66-8. doi.org/10.1016/j.chieco.2006.10.005

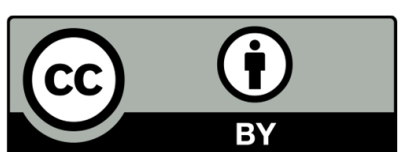

(C) 2022 by the authors; licensee Growing Science, Canada. This is an open access article distributed under the terms and conditions of the Creative Commons Attribution (CC-BY) license (http://creativecommons.org/licenses/by/4.0/). 